\section{Jurnal Mitra Pendidikan (JMP Online)}

URL : http://e-jurnalmitrapendidikan.com
JMP Online

Vol. 4, No. 8, 526-537.

(C) 2020 Kresna BIP. e-ISSN 2550-0481 p-ISSN 2614-7254

\title{
UPAYA MENINGKATKAN PRESTASI BELAJAR PESERTA DIDIK \\ DI DAERAH TERPENCIL MELALUI PEMANFAATAN ALAM \\ DI SDK LAMANUNA KECAMATAN ATADEI KABUPATEN LEMBATA
}

\author{
Antonius Ata
}

SDK Lamanuna Kabupaten Lembata

INFORMASI ARTIKEL

Dikirim : 22 Agustus 2020

Revisi pertama : 25 Agustus 2020

Diterima : 25 Agustus 2020

Tersedia online : 29 Agustus 2020

Kata Kunci: Prestasi, Alam, Media

Email:antonius@gmail.com
ABSTRAK

Penelitian ini adalah penelitian tindakan sekolah yang dilakukan kepala sekolah untuk meningkatkan prestasi peserta didik di daerah terpencil melalui pemanfaatan alam di SDK Lamanuna.

Tujuan dari penelitian ini adalah untuk mengetahui prestasi belajar peserta didik di daerah terpencil melalui pemanfaatan alam di SDK Lamanuna Kecamatan Atadei Kabupaten Lembata.

Hasil pembahasan adalah pada siklus I kepala sekolah mengalami kesulitan pada saat mengamati dan mengajar. Guru masih menggunakan metode ceramah dengan menggunakan buku pelajaran sebagai media dalam pembelajaran sedangkan pada siklus II, kepala sekolah sebagai peneliti membuat jadwal mengajar untuk mempermudah pengamatan dan membuat jadwal pengecekan penggunakan metode pembelajaran dan media pembelajaraan melalui pemanfaatan alam sehinnga dapat meningkatkan prestasi belajar peserta didik di SDK Lamanuna.

Dari hasil penelitian dapat disimpulkan bahwa dalam menerapkan dan menggunakan media pembelajaran guru harus kreatif dengan memanfaatkan media yang ada disekitanya. Pembagian jadwal mengajar perlu ditingkatkan lagi sehingga dapat meningkatkan efektifitas waktu yang ada. 


\section{PENDAHULUAN \\ Latar Belakang}

Dunia pendidikan adalah salah satu hal penting yang harus dinikmati oleh generasi penerus bangsa. Demikian juga bangsa Indonesia yang terbentang dari Sabang sampai Mauroke yang terdiri dari berbagai latar belakang kehidupan yang beraneka ragam dengan tingkat pendidikan yang berbeda pula. Di jaman sekarang yang serba canggih dengan berbagai teknologi pembangunan perlu dinikmati setiap insan manusia sebagai generasi penerus bangsa. Pendidikan di Indonesia sudah berkembang pesat sampai kepelosok-pelosok daerah bahkan sampai daerah yang terpencil, pemerintah memperhatikan dengan membuka sekolah- sekolah baik tingkat TK/PAUD sampai tingkat SMA. Tugas kita untuk menjalankan program pemerintah dengan menyekolahkan peserta didik yang memasuki usia sekolah. Sebagai orang tua harus menyekolahkan anak-anaknya sampai ke tingkat perguruan tinggi jika mampu untuk membiayainya. Ada juga program pemerintah lainnya yaitu dengan memberikan beasiswa bagi anak yang berprestasi. Pemerintah menyediakan berbagai fasilitas yang penunjang pendidikan agar generasi penerus menjadi generasi yang berpendidika dan berbudi pekerti. Untuk menyambung tangan dari pemerintah, maka pemerintah memberikan tugas kepada kepala sekolah baik tingkat sekolah menengah kebawah sampai menengah atas. Kepala sekolah yang akan ditugaskan harus bertanggungjawab dan bekerja dengan hati, apalagi yang mendapat tugas di daerah terpencil yang jauh dari pusat kota.

Hal ini juga dialami kepala sekolah SDK Lamanuna. Sebagai seorang kepala sekolah siap menerima tugas yang diberikan dan bertanggungjawab. SDK Lamanuna adalah salah satu sekolah yang terletak di Desa Dulir Kecamatan Atadei Kabupaten Lembata. Jalan menuju SDK Lamanuna sangat jauh berada di pantai selatan pulau Lembata. Topografi yang dikelilingi bukit dan jurang dan jalan yang sebagian besarnya masih tanah dan bebatuan sangat menantang bagi yang berkunjung ke sekolah tersebut. Akses menuju SDK Lamanuna hanya bisa menggunakan kendaraan roda dua, pick up dan truck. Jumlah penduduk yang berada di desa Dulir sebanyak 300 jiwa dari 26 kepala keluarga. Mata pencaharian penduduk sebagian besarnya adalah petani dengan tingkat pendidikan rata- rata tamatan SD. Jumlah peserta didik yang sekolah di SDK Lamanuna sebanyak 21 orang. Walaupun dengan keadaan lokasi sekolah yang berada di daerah terpencil, namun upaya untuk meningkatkan prestasi belajar siswa selalu diperhatikan kepala sekolah dan guru bantu dalam mendidik peserta didiknya. Peningkatan prestasi belajar siswa yang didukung dengan fasilitas sekolah yang cukup baik dimana gedung sekolah yang baik dan fasilitas buku pelajaran yang lengkap. Kekurangan yang terjadi di sekolah adalah ada sebuah bangunan yang berada di sebelah barat sekolah yang rusak berat, lingkungan sekolah yang terlihat gersang karena daerah tersebut tidak ada air yang masuk sampai ke sekolah hanya diharapkan air hujan yang ditampung di bak penampungan. Dengan melihat keadaan sekolah ini, sebagai kepala sekolah akan berusaha untuk meningkatkan prestasi belajar peserta didiknya dengan memanfaatkan alam yang ada di sekolah sebagai media untuk belajar. Guru yang mengajar di sekolah ini adalah kepala sekolah dan satu orang guru bantu. 
Berdasarkan latar belakang masalah ini, maka kepala sekolah sebagai peneliti akan melakukan penelitian di SDK Lamanuna dengan mengambil judul "Upaya Meningkatkan Prestasi Belajar Peserta Didik di Daerah Terpencil Melalui Pemanfaatan Alam di SDK Lamanuna Kecamatan Atadei Kabupaten Lembata.

\section{Rumusan Masalah}

Rumusan masalah dalam penelitian ini adalah bagaimana meningkatkan prestasi belajar peserta didik di daerah terpencil melalui pemanfaatan alam di SDK Lamanuna Kecamatan Atadei Kabupaten Lembata?".

\section{Tujuan Penelitian}

Tujuan dari penelitian ini adalah untuk mengetahui prestasi belajar peserta didik di daerah terpencil melalui pemanfaatan alam di SDK Lamanuna Kecamatan Atadei Kabupaten Lembata.

\section{Manfaat Penelitian}

Manfaat dalam penelitian ini adalah sebagai berikut.

1. Bagi Peserta Didik

Untuk meningkatkan prestasi belajar peserta didik melalui pemanfaatan alam

2. Bagi Guru

Untuk meningkatkan kompetensi guru dalam pembelajaran

3. Bagi Kepala Sekolah

Sebagai bahan refleksi untuk meningkatkan mutu pendidikan di SDK Lamanuna.

\section{KAJIAN PUSTAKA}

Pengertian Prestasi Belajar

Belajar merupakan kebutuhan semua orang, sebab dengan belajar seseorang dapat memahami atau menguasai sesuatu sehingga kemampuannya dapat ditingkatkan.

Menurut Chaplin (2011), "Prestasi merupakan hasil yang dicapai (dari yang dilakukan dan diharapkan). Dari definisi tersebut maka prestasi belajar adalah penguasaan pengetahuan dan ketrampilan yang dikembangkan oleh mata pelajaran, yang lazimnya ditujukan dengan nilai-nilai atau angka-angka yang diberikan oleh negara.

Menurut Ahmad Dahlan. (2014) belajar pada manusia dapat dirumuskan sebagai suatu aktivitas mental atau psikis yang berlangsung dalam interaksi aktif dengan lingkungan, yang menghasilkan perubahan-perubahan dalam pengetahuan dan nilai sikap. Perubahan itu bersifat relatif konstan dan berbekas.

Belajar tidak hanya dapat dilakukan di sekolah saja, namun dapat dilakukan dimana-mana, seperti di rumah ataupun dilingkungan masyarakat. Irwanto (1997) berpendapat bahwa belajar merupakan proses perubahan dari belum mampu menjadi sudah mampu dan terjadi dalam jangka waktu tertentu. 


\section{Pengertian Daerah Terpencil}

Desa terpencil adalah persekutuan hidup permanen pada suatu tempat, kampung dengan sifat yang khas yaitu; kekeluargaan, adanya kolektivitas dalam pembagian tanah dan pengerjaannya serta ada kesatuan ekonomis yang memenuhi kebutuhan sendiri.

\section{Kategori Daerah Terpencil Faktor}

Penyebab Suatu daerah dikategorikan sebagai daerah terpencil dan tertinggal antara lain : Geografis.Umumnya secara geografis daerah terpencil relatif sulit dijangkau karena letaknya yang jauh di pedalaman, perbukitan/pegunungan, kepulauan, pesisir, dan pulau-pulau terpencil atau karena faktor geomorfologis lainnya sehingga sulit dijangkau oleh jaringan baik transportasi maupun media komunikasi. Sumberdaya Alam.Beberapa daerah terpencil tidak memiliki potensi sumberdaya alam, daerah yang memiliki sumberdaya alam yang besar namun lingkungan sekitarnya merupakan daerah yang dilindungi atau tidak dapat dieksploitasi, dan daerah tertinggal akibat pemanfaatan sumberdaya alam yang berlebihan. Sumberdaya Manusia. Pada umumnya masyarakat di daerah terpencil mempunyai tingkat pendidikan, pengetahuan, dan keterampilan yang relatif rendah serta kelembagaan adat yang belum berkembang. Prasarana dan Sarana. Keterbatasan prasarana dan sarana komunikasi, transportasi, air bersih, irigasi, kesehatan, pendidikan, dan pelayanan lainnya yang menyebabkan masyarakat di daerah terpencil tersebut mengalami kesulitan untuk melakukan aktivitas ekonomi dan sosial.

\section{Teori Pilihan Rasional}

Teori pilihan rasional umumnya berada dipinggiran aliran utama sosiologi tahun 1989 dengan tokoh yang cukup berpengaruh adalah Coleman.Teori pilihan rasional oleh James S. Coleman adalah tindakan perseorangan kepada sesuatu tujuan dan tujuan itu (juga tindakan) ditentukan oleh nilai atau pilihan.Teori pilihan rasional memusatkan perhatian pada aktor dimana aktor dipandang sebagai manusia yang mempunyai tujuan atau mempunyai maksud artinya aktor mempunyai tujuan dan tindakan tertuju pada upaya untuk mencapai tujuan tersebut, actorpun dipandang mempunyai pilihan atau nilai serta keperluan. Teori pilihan rasional tidak menghiraukan apa yang menjadi pilihan atau apa yang menjadi sumber pilihan aktor, yang penting adalah pernyataan bahwa tindakan dilakukan untuk mencapai tindakan yang sesuai dengan pilihan aktor.

Teori pilihan rasional Coleman tampak jelas dalam gagasan dasarnya bahwa tindakan perseorangan mengarah pada suatu tujuan dan tujuan itu ditentukan oleh nilai atau pilihan, tetapi selain Coleman menyatakan bahwa untuk maksud yang sangat teoritis, ia memerlukan konsep yang lebih tepat mengenai aktor rasional yang berasal dari ilmu ekonomi dimana memilih tindakan yang dapat dimaksimalkan kegunaan atau yang dapat memuaskan keinginan dan kebutuhan mereka (Ritzer, 2012:394).

Ada dua unsur utama dari teori Coleman, yakni aktor dan sumber daya adalah sesuatu yang menarik perhatian dan yang dapat dikontrol oleh aktor. Coleman mengakui bahwa dalam kehidupan nyata orang tak selalu berprilaku 
rasional, namun ia merasa bahwa hal ini hampir tak berpengaruh pada teorinya. Pemusatan perhatian pada tindakan rasioanal inndividu dilanjutkan dengan memusatkan perhatian pada masalah hubungan mikro-makro atau bagaimana cara gabungan tindakan individu menimbulkan perilaku sistem sosial. Inti dari penjelasan teori pilihan rasional adalah bahwa pilihan. Keyakinan, dan tindakan memiliki hubungan satu sama lain. Sebuah tindakan akan dikatakan rasional bila tindakan tersebut dapat dibuktikan sebagai tindakan yang paling dapat memuaskan pilihan sipelaku sesuai dengan keyakinan yang ia miliki dan dibuktikan secara ex post (yaitu ketika dibandingkan dengan hasil nyatanya) biarpun secara ex ente (sebelum dampaknya diketahui, keputusannya sudah rasional).

Keyakinan akan dikatakan bila sesuai dengan bukti-bukti yang ada. Untuk membuktikan bahwa sebuah tindakan adalah rasional, kita harus menunjukkan sebuah deret dimana tindakan tersebut dipandang sebagai terberi (given) tapi segala sesuatu yang harus dibenarkan atau dicarikan alasannya. Dalam membuat pilihan, individu diawali dengan adanya keinginan terhadap sesuatu dan keyakinan terhadap tujuan-tujuan tertentu yang disusun dalam suatu keyakinan. Keyakinankeyakinan inilah yang pada akhirnya akan menciptakan pilihan rasional para individu.

Keyakinan masyarakat untuk berdomisili di desa terpencil merupakan pilihan dari setiap individu pada masyarakat. Seperti pada masyarakat desa di sekitar SDK Lamanuna, mereka mempunyai orientasi masing-masing yang menjadi alasan untuk berdomisili di desa tersebut seperti menggarap lahan yang kosong, memanfaatkan hasil sumber daya alam yang terdapat disekitar tempat tingal dan alasan lainnya seperti mempertahankan hubungan kekerabatan maupun kekeluargaan yang terjalin sejak lama.

\section{Pengertian Pemanfaatan Alam}

Cinta lingkungan bukanlah hal yang secara instan muncul dalam kehidupan seseorang. Kepedulian terhadap lingkungan sekitar perlu diperkenalkan sejak dini, termasuk kepada siswa. Caranya dengan sekaligus memanfaatkan lingkungan alam sebagai media pembelajaran. Jenis lingkungan sebagai media pembelajaran untuk siswa SD sangat banyak dan beragam. Dengan demikian, guru perlu memiliki kemampuan untuk mengindentifikasi berbagai potensi yang ada pada lingkungan tersebut, dikaitkan dengan kemampuan yang harus diperoleh siswa. Khususnya yang telah tertera dalam kurikulum. Misalnya, berupa rumusan kompetensi untuk mata pelajaran tertentu.

Demikian pula guru pun harus mampu memanfaatkannya secara maksimal. Sehingga, dapat membantu mengembangkan berbagai potensi dan kemampuan siswa secara optimal. Potensi lingkungan yang demikian banyak tersebut akan menjadi sia-sia jika guru tidak peka dan tidak kreatif dalam memanfaatkannya. Sebenarnya lingkungan menjadi media pembelajaran yang potensial, faktual serta fungsional bagi anak dalam mencapai kemampuan-kemampuan belajar yang diharapkan. Pada dasarnya, semua lingkungan yang ada di sekitar siswa dapat dimanfaatkan untuk mengoptimalkan kegiatan pembelajaran di SD. Hal itu sepanjang relevan dengan kompetensi dasar dan hasil belajar yang diharapkan dicapai siswa. Dari semua lingkungan yang dapat digunakan dalam proses 
pendidikan dan pembelajaran, secara umum dapat dikategorikan menjadi tiga macam lingkungan belajar. Yakni, lingkungan alam, lingkungan sosial dan lingkungan buatan. Manfaat media berbasis lingkungan seperti: siswa dapat lebih memahami gejala-gejala alam yang terjadi dalam kehidupan sehari-hari, menumbuhkan kesadaran sejak awal untuk mencintai alam, siswa dapat memperlakukan alam sebagai satu kesatuan yang utuh dan menyeluruh, lingkungan menyediakan berbagai hal yang dapat dipelajari siswa, dan penggunaan lingkungan memungkinkan terjadinya proses belajar yang lebih bermakna (meaningfull learning).

Dengan memahami dan menghayati aspek-aspek kehidupan yang ada di linkungan siswa, dapat memungkinkan terjadinya proses pembentukan kepribadian siswa ke arah yang lebih baik. Kegiatan belajar dimungkinkan akan lebih menarik bagi siswa. Sebab, lingkungan menyediakan media pembelajaran yang sangat beragam dan banyak pilihan. Selain itu, memanfaatan lingkungan menumbuhkan aktivitas belajar sswa yang lebih meningkat dengan dimungkinkannya penggunaan berbagai cara atau metode pembelajaran yang bervariasi. Lingkungan alam atau lingkungan fisik adalah segala sesuatu yang sifatnya alamiah. Seperti, sumber daya alam (air, hutan, tanah dan batu-batuan), flora dan fauna, fenomena alam (sungai, danau, gunung, pegunungan, lembah, ngarai, pantai, laut), serta cuaca, iklim, dan berbagai musim. Lingkungan alam sifatnya relatif menetap. Oleh karena itu jenis lingkungan ini akan lebih mudah dikenal dan dipelajari oleh siswa. Sesuai dengan kemampuannya, siswa dapat mengamati perubahan-perubahan yang terjadi dan dialami dalam kehidupan sehari-hari, termasuk juga proses terjadinya. Misalnya mengenai terjadinya perubahan siang dan malam, suhu udara pagi dan siang hari, hujan dan panas. Masalah kerusakan lingkungan dan penyebabnya dapat juga dipelajari oleh siswa. Seperti erosi, hutan gundul, pencemaran air, udara, tanah, dan sebagainya. Tentu saja cara mempelajarinya harus disesuaikan dengan tingkat perkembangan dan kemampuan siswa SD.

Dengan mempelajari lingkungan alam ini, diharapkan siswa dapat lebih memahami gejala-gejala alam yang terjadi dalam kehidupannya sehari-hari. Lebih dari itu diharapkan juga dapat menumbuhkan kesadaran sejak awal untuk mencintai alam. Siswa tentu akan memperoleh susuatu yang sangat berharga dari kegiatan belajarnya yang mungkin tidak akan ditemukan dari pengalaman belajar di kelas. Dengan mempelajari lingkungan alam sekitar, siswa dapat memperlakukan alam sebagai satu kesatuan utuh dan menyeluruh. Alam tidak dipandang sebagai ciptaan Tuhan yang berdiri sendiri dan sia-sia. Melainkan sebagai tempat berinteraksi. Berinteraksi dengan lingkungan alam sekitar akan menimbulkan penghayatan baru dalam diri siswa tentang keterkaitan antarlingkungan. Penghayatan baru terhadap keterkaitan berbagai lingkungan, akan lebih mendalam dan meluas manakala didukung oleh praktik pendidikan lingkungan yang terencana dan berkesinambungan. 


\section{METODE PENELITIAN}

\section{Jenis, Lokasi dan Subyek Penelitian}

Jenis penelitian adalah penelitian tindakan sekolah (PTS). Lokasi penelitian di SDK Lamanuna Kecamatan Atadei Kabupaten Lembata dan subyek penelitian adalah peserta didik. Penelitian ini dilaksanakan pada bulan Agustus hingga September 2019.

\section{Teknik Pengumpulan Data}

Data diperoleh dari hasil pengamatan, wawancara dan catatan lapangan untuk penilaian proses :

1. Hasil pengamatan

Pengamatan dilakukan oleh peneliti pada saat proses setelah tindakan dilakukan, hasil pengamatan terekam dalam format pengamatan.

2. Wawancara

Wawancara dilakukan oleh peneliti setelah tindakan dilakukan. Wawancara dilakukan untuk mengetahui kemampuan peserta didik dan guru dalam menguasai pelajaran serta kesulitan-kesulitannya.

\section{Teknis Analisis Data}

Data yang dianalisis adalah data dari hasil observasi, wawancara dan cacatan lapangan yang diperoleh sebelum dan selama berlangsungnnya penelitian tindakan sekolah.

Teknik analisis data yang digunakan adalah secara kualitatif, yaitu dengan menghitung besarnya prosesntase dari masing-masing indikator penelitian. Pengumpulan data yang dilakukan melalui pengamatan, wawancara, catatan lapangan, dianalisis sejak proses berlangsung penelitian, sehingga hal ini menunjukan bahwa penelitian tindakan sekolah prosesnya bersamaan pada saat pengumpulan data.

Diharapkan data dari hasil penelitian ini dapat menggambarkan mengenai keadaan sekolah di SDK Lamanuna. Hal ini akan tampak dari hasil perhitungan prosentasenya dari kegiatan di siklus I yang dibandingkan dengan hasil di siklus II.

\section{HASIL PENELITIAN DAN PEMBAHASAN Hasil Penelitian}

Dalam melaksanakan kegiatan penelitian, tentunya penulis sudah mengetahui langkah- langkah apa saja yang akan dibuat. Langkah-langkah yang harus disiapkan akan dijelaskan dibawah ini.

\section{Siklus I}

1. Perencanaan

Sebelum melakukan pelaksanaan penelitian, peneliti dalam hal ini kepala sekolah melakukan pengamatan awal untuk mengidentifikasi permasalahan yang perlu diatasi dengan melakukan wawancara langsung kepada peserta didik dan guru. Kepala sekolah dibantu oleh gurunya sebagi observer dalam penelitian. Kepala sekolah berdiskusi dengan guru bantu 
tentang maksud dan tujuan diadakan penelitian. Setelah guru bantunya paham, maka kepala sekolah menentukan jadwal penelitian. Jadwal penelitian adalah bulan Agustus sampai September 2019. Pada bulan Oktober, kepala sekolah akan membuat laporan penelitian dan hasil penulisan. Setelah membuat jadwal penelitian dan langkah- langkah pelaksanaan penelitian, maka kepala sekolah mulai melaksanakan penelitian yang akan dibahas pada pelaksanaan tindakan.

2. Pelaksanaan Tindakan

Siklus I dilaksanakan selama bulan Agustus 2019. Kegiatan awal yang dilakukan kepala sekolah adalah melakukan pengamatan langsung aktifitas peserta didik dan guru saat pembelajaran. Dalam pengamatan berlangsung selama satu bulan hasil yang dicapai adalah kepala sekolah mengalami kesulitan karena selain mengamati kepala sekolah juga mengajar. Kepala sekolah dan guru bantu melaksanakan pembelajaran kepada peserta didik di depan teras sekolah maksudnya untuk mempermudah pengontrolan saat pengamatan. Jumlah rombel yang ada peserta didiknya adalah kelas 2 sebanyak 10 orang dan kelas 4 sebanyak 9 orang, sedangkan kelas yang lain tidak ada peserta didik. Kepala sekolah mengajar kelas 2 dan guru bantu mengajar kelas 4. Setiap hari KBM berjalan dengan baik. Masing- masing mengajar dua mata pelajaran per hari dengan 3 jam pelajaran. Kepala sekolah menentukan jadwal mengajarnya sehingga saat pengamatan dan penilaian mudah dikontrol. Kegiatan KBM enam hari seminggu. Dari hasil pengamatan dalam kegiatan pembelajaran guru masih menggunakan pola lama yaitu ceramah, bertanya dan pemberian tugas kepada peserta didik. Guru minim menerapkan metode pembelajaran yang menyenangkan dan dapat meningkatkan prestasi belajar peserta didiknya.

Hasil pengamatan yang dilihat umumnya setiap hari melaksanakan KBM, peserta didik dibagi dalam kelompok diskusi. Media pembelajaran yang digunakan adalah buku pelajaran dan batuan atau biji-bijian sebagai media untuk berhitung. Dengan melihat hal yang dialami ini, maka kepala sekolah sebagai peneliti akan mencari jalan keluar agar masalah atau kendala yang dialami ini dapat diatasi dengan mengubah system belajar sehingga dapat meningkatkan prestasi belajar peserta didik dan mutu pembelajaran bagi guru. Dengan demikian kepala sekolah akan melakukan penelitian ulang pada siklus II.

3. Pengamatan Hasil Tindakan

Dalam pelaksanaan siklus I ini, pengamatan tehadap kegiatan pembelajaran belum dijalankan secara baik karena kepala sekolah dan guru bantu melaksanakan kegiatan pembelajaranpada jamyang sama yaitu pada jam pertama dan jam kedua, sehingga dalam pengamatan berlangsung belum maksimal. Hasil yang dicapai yang baik adalah selama bulan Agustus kegiatan pembelajaran berjalan dengan baik dan aktivitas dari siswa cukup baik. Kelemahan yang terjadi adalah kepala sekolah belum membuat angket penilaian observer hanya pengamatan secara umum.

4. Refleksi

Hasil pelaksanaan siklus I cukup berjalan dengan cukup baik, walaupun persiapan dari kepala sekolah belum maksimal melihat kondisi sekolah dimana 
guru yang ada hanya satu orang dan jumlah siswa yang sedikit. Aktifitas selama penelitian siklus I kepala sekolah sebagai peneliti mengalami kesulitan pada waktu pengamatan karena guru bantu juga mengajar pada jam yang sama sehingga hal-hal yang akan diteliti tidak diteliti dengan baik seperti penerapan metode pada waktu kegiatan pembelajaran. Kuntungan yang diperoleh adalah semua peserta didik hadir selama pelaksanaan siklus I.

\section{Siklus II}

1. Perencanaan

Pelaksanaan siklus II akan dilaksanahan pada bulan September 2019. Pelaksanaan siklus II ini untuk menjawab kelemahan yang terjadi pada siklus I. Sebelum melakukan penelitian, kepala sekolah mengadakan diskusi ulang dengan guru bantu sebagai observer dan membuat persiapan yang lebih matang lagi sebelum melaksanaakan kegiatan siklus II. Kepala sekolah menentukan jadwal kegiatan selama satu bulan. Maksud penelitian ini adalah untuk mengetahui bagaimana penerapan model pembelajaran pada setiap mata pelajaran dan media apa yang digunakan. Kepala sekolah memberikn motivasi kepada guru bantunya agar dalam menerapkan metode pembelajaran dapat memanfaatkan alam di lingkungan sekitar sekolah. Melihat lokasi SDK Lamanuna berada di daerah terpencil yang dikelilingi bukit- bukit dan alam yang masih asli. Kepala sekolah akan membagi jadwal penelitian dalam mengajar secara bergilir dengan maksud agar waktu pengamatan bisa dilakukan dengan baik.

2. Pelaksanaan Tindakan

Pelaksanaan siklus II, akan dilaksanakan sesuai dengan jadwal yang sudah ditentukan pada perencanaan siklus II sehingga dalam pengamatan aktifitas siswa dan guru dapat berjalan dengan baik. Pelaksanaan siklus II ini selama 2 minggu kegiatan yaitu minggu pertama dan minggu kedua. Pada minggu pertama dan kedua kegiatan berjalan dengan baik. Model pembelajaran dan media yang diterapkan masing-masing dalam pembelajaran dapat digunakan dengan baik. Dalam aktivitas pembelajaran selama pengamatan berlangsung pada setiap pelajaran model pembelajaran yang diterapkan guru pada pelajaran dan media yang digunakan meningkat dengan baik walaupun media yang digunakan sederhana yaitu dengan memanfaatkan alam sekitar sekolah. Peserta didik menikmati dan mengikuti pelajaran dengan baik. Dalam pengamatan setelah dibagi dalam jadwal, maka kepala sekolah dan guru dapat mengontrol dengan baik. Hasil pengamatan aktivitas guru dan penerapan model pembelajaran dapat dilihat pada tabel-tabel dibawah ini. 
3. Pengamatan Hasil Tindakan

Tabel 1. Pengamatan Aktivitas Guru Pada Siklus II

\begin{tabular}{|c|c|c|c|c|c|}
\hline \multirow{2}{*}{ No } & \multirow{2}{*}{ Hal-Hal yang Dinilai } & \multicolumn{2}{|c|}{ SKOR } & \multirow{2}{*}{ Jumlah } & \multirow{2}{*}{$\begin{array}{l}\text { Rata- } \\
\text { Rata }\end{array}$} \\
\hline & & Observer 1 & Observer 2 & & \\
\hline 1 & $\begin{array}{l}\text { PERSIAPAN } \\
\text { Perencanaan Pembelajaran }\end{array}$ & 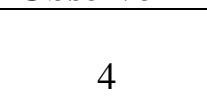 & 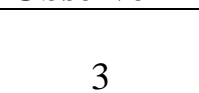 & 7 & 3,5 \\
\hline 2 & Penampilan penyaji & 3 & 3 & 6 & 3 \\
\hline 3 & $\begin{array}{l}\text { PENYAJIAN } \\
\text { B.1 Pendahuluan } \\
\text { Pemeriksaan kehadiran peserta } \\
\text { didik }\end{array}$ & 3 & 3 & 6 & 3 \\
\hline 4 & Pelaksanaan pembelajaran & 3 & 4 & 7 & 3,5 \\
\hline 5 & Pengungkapan tujuan pembelajaran & 4 & 3 & 7 & 3,5 \\
\hline 6 & $\begin{array}{l}\text { B.2 Kegiatan Inti } \\
\text { Penerapan model pembelajaran }\end{array}$ & 4 & 3 & 7 & 3,5 \\
\hline 7 & $\begin{array}{lll}\begin{array}{l}\text { Pemanduan } \\
\text { pembelajaran }\end{array} & \text { sajian } & \text { materi }\end{array}$ & 3 & 3 & 6 & 3 \\
\hline 8 & $\begin{array}{l}\text { Pembahasan hasil kerja melibatkan } \\
\text { keaktifan peserta didik }\end{array}$ & 3 & 3 & 6 & 3 \\
\hline 9 & Pemberian bimbingan siswa & 3 & 3 & 6 & 3 \\
\hline 10 & $\begin{array}{l}\text { PENUTUP } \\
\text { Penggunaan system perbaikan }\end{array}$ & 3 & 3 & 6 & 3 \\
\hline 11 & $\begin{array}{l}\text { Pemberian tindaklanjut atau tugas } \\
\text { perbaikan }\end{array}$ & 4 & 4 & 8 & 4 \\
\hline & Jumlah & 37 & 35 & 72 & 36 \\
\hline & Rata-rata & 3,3 & 3,1 & 6,5 & 3,2 \\
\hline & Persentase Perolehan & $84 \%$ & $79 \%$ & & $80 \%$ \\
\hline
\end{tabular}

Sumber : Hasil Penelitian, diolah (2019)

Berdasarkan tabel 1 aktivitas guru pada siklus II mengalami peningkatan yang lebih baik bila dibandingkan pada siklus I masih mengalami kekurangan atau kelemahan sehingga pada siklus II ini sudah ada kemajuan pada tahap perencanaan pembelajaran, pelaksanaan pembelajaran, pengungkapan tujuan pembelajaran, penerapan model pembelajaran, pembahasan hasil kerja yang melibatkan keaktifan siswa.

Tabel 2. Penerapan Metode dan Media Pembelajaran pada Siklus II

\begin{tabular}{|c|c|c|c|c|c|c|}
\hline \multirow{2}{*}{ No } & \multirow{2}{*}{ Hari } & $\begin{array}{c}\text { Mata } \\
\text { Pelajaran }\end{array}$ & \multicolumn{2}{c|}{ Model Pembelajaran } & \multicolumn{2}{c|}{ Media yang Digunakan } \\
\hline 1 & Senin & $\begin{array}{c}\text { Bahasa } \\
\text { Indonesia }\end{array}$ & Bermain Peran & Kelas 4 & Kelas 2 & Kelas 4 \\
\hline & Peran & $\begin{array}{c}\text { Kartu } \\
\text { Huruf }\end{array}$ & $\begin{array}{c}\text { Buku Pelajaran } \\
\text { Bahasa } \\
\text { Indonesia }\end{array}$ \\
\hline 2 & Selasa & Matematika & Demonstrasi & Diskusi & $\begin{array}{c}\text { Kartu } \\
\text { Angka }\end{array}$ & Lidi \\
\hline 3 & Rabu & PKn & Diskusi & Diskusi & - & - \\
\hline
\end{tabular}


Lanjutan Tabel 2. Penerapan Metode dan Media Pembelajaran pada Siklus II

\begin{tabular}{|c|c|c|c|c|c|c|}
\hline \multirow{2}{*}{ No } & \multirow{2}{*}{ Hari } & \multirow{2}{*}{$\begin{array}{c}\text { Mata } \\
\text { Pelajaran }\end{array}$} & \multicolumn{2}{c|}{ Model Pembelajaran } & \multicolumn{2}{c|}{ Media yang Digunakan } \\
\cline { 4 - 7 } & & Kelas 2 & Kelas 4 & Kelas 2 & Kelas 4 \\
\hline 4 & Kamis & IPA & Demonstrasi & Diskusi & $\begin{array}{c}\text { Anggota } \\
\text { Tubuh }\end{array}$ & Alam \\
\hline 5 & Jumat & IPS & Diskusi & Diskusi & - & Alam \\
\hline 6 & Sabtu & PAK & Bermain Peran & Demonstrasi & - & - \\
\hline
\end{tabular}

Sumber : Hasil Penelitian, diolah (2019)

Dari hasil yang diperoleh, guru telah menerapkan metode pada setiap mata pelajaran dengan menggunakan media yang ada di sekitar lingkungan sekolah. Walaupun sederhana namun, kepala sekolah puas karena guru telah menerapkan metode pembelajaran sesuai dengan kemampuan yang dimiliki peserta didik. Pembelajaran ini sangat membantu aktivitas dan perkembangan belajar bagi peserta didik sehingga dapat meningkatkan prestasinya.

4. Refleksi

Setelah merenung kembali pelaksanaan kegiatan penelitian siklus II, ternyata ada keuntungan yang dicatat kepala sekolah sebagai bahan renungan yaitu:

a. Pelaksanaan siklus II dapat berjalan dengan baik

b. Dapat mengetahui aktivitas guru setiap hari

c. Dapat mengetahui penerapan metode dan media pembelajaran pada mata pelajaran yang bersangkutan

d. Dapat mengetahui perkembangan peserta didik setiap hari

Kelemahan yang diperoleh adalah

a. Penerapan model pembelajaran sesuai dengan kemampuan peserta didik

b. Media yang digunakan sangat sederhana

c. Guru belum banyak mengetahui metode pembelajaran yang digunakan

Dengan melihat hasil dari renungan ini maka menjadi bahan refleksi bagi kepala sekolah dalam meningkatkan prestasi belajar peserta didik didaerah terpencil melalui pemanfaatan lingkungan alam perlu ditingkatkan lagi baik bagi guru dalam penerapan metode pembelajaran maupun prestasi peserta didik sehingga dapatmeningkatkan mutu pendidikan di SDK Lamanuna.

\section{KESIMPULAN DAN SARAN \\ Kesimpulan}

Pelaksanaan siklus I dan siklus II dalam penelitian tentang meningkatkan prestasi peserta didik di daerah terpencil dengan memanfaatkan lingkungan alam dapat disimpulkan sebagai berikut :

a. Dalam menerapkan dan menggunakan media pembelajaran guru harus kreatif dengan memanfaatkan media yang ada disekitanya.

b. Penerapan model pembelajaran dapat disesuaikan dengan kemampuan peserta didiknya

c. Pembagian jadwal mengajar perlu ditingkatkan lagi sehingga dapat meningkatkan efektifitas waktu yang ada. 
d. Dapat mengetahui kekurangan dan kelebihan sarana dan prasarana yang ada di sekolah

\section{Saran}

Setelah mengadakan penelitian ini dan hasil yang dicapai pada siklus I dan siklus II maka dapat disarankan :

a. Untuk penelitian lanjutan perlu dipaparkan hasil laporan kegiatan pembelajaran ke publik sebagai bahan kajian informasi.

b. Memberikan motivasi kepada guru bantu untuk mengikuti pelatihan tentang penelitian tindakan kelas

\section{DAFTAR PUSTAKA}

Ahmad Dahlan. 2014. Definisi Prestasi Belajar dan Faktor-Faktor Prestasi Belajar. Diakses dari laman web tanggal 17 Juli 2017 dari: http://www.eurekapendidikan.com/2015/03/definisi-prestasi-belajardanfaktor.html

Bintarto,R. 2012. Pengantar Geografi Kota. Yogyakarta: Spring

Chaplin. 2011. Kamus Lengkap Psikologi (terjemahan Kartini Kartono). Jakarta: PT. Raja Grafindo Persada.

Darsono. 2010. Manajemen Keuangan. Jakarta: Consultant Accounting Kartohadikusumo, Soetardjo. 2010. Desa, Jogjakarta: Sumur Bandung,

Ogburn, William F and Mayer F Nimmkoff. 2010. Sociology. Boston: A Pfeffer and Simmons International University Edittion, Toughton Miffilin Company

Peraturan Pemerintah Nomor 72 Tahun 2005 Tentang Desa.

Ritzer, George. 2012. Teori Sosiologi. Yogyakarta : Pustaka Pelajar.

Atlas Ronald M, Snyder James W. 2014. Handbook of medical for Clinical and Public Health Microbiology. Francis : Crc Press 